\title{
Characterization studies on Agbaja iron ore: a high-phosphorus content ore
}

\author{
Stanley Udochukwu Ofoegbu ${ }^{1,2}$ (1)
}

(C) Springer Nature Switzerland AG 2019

\begin{abstract}
Characterization of Agbaja iron ore was carried out using optical microscopy, scanning electron microscopy with energydispersive X-ray spectroscopy, X-ray fluorescence spectrometry, powder X-ray diffraction, thermal gravimetry, and differential scanning calorimetry. The ore consists of a matrix of gangue minerals composed principally of aluminosilicates and iron-rich concentric cored structures characteristic of oolitic ores. Chemical analyses of the ore indicate that it is principally composed of $53.1 \mathrm{wt} \% \mathrm{Fe}, 1.395 \mathrm{wt} \% \mathrm{P}$, and aluminosilicates. The phosphorus associated with the ore was found to be present in both the iron-rich mineral(s) and the gangue minerals, indicating that beneficiation by elimination of gangue will have little effect on the percentage of phosphorus in the valuable mineral. Based on the results, it is postulated that phosphorus in Agbaja iron ore is most probably present in an amorphous phase and not as a component element of a distinct crystalline phase.
\end{abstract}

Keywords Iron ore · High phosphorus · Oolitic · Goethite · Dehydroxylation · Elemental distribution

\section{Introduction}

For an iron ore deposit to be considered economically recoverable, it must contain at least $25 \%$ iron [1]. However, ores with iron content lower than $25 \%$ can still be economically exploited if the ore deposit is large (economy of scale), can be concentrated (beneficiation), and can be transported cheaply [2]. Out of more than 300 ironbearing minerals, five (haematite, magnetite, maghemite, goethite, and siderite) are the primary sources of iron ore minerals for steelmaking [1]. Phosphorous is reported to be usually present in secondary iron oxide minerals, such as limonite, ochre, goethite, secondary haematite, and alumina-rich minerals such as clay and gibbsite, and in apatite/hydroxyapatite in magnetite ores [3]. The acceptable levels of $P$ in hot metal range from 0.08 to 0.14 [4]; hence, iron ores for steelmaking with very low phosphorus contents are desirable. Iron ores can be classified with respect to their phosphorus content as low-phosphorus ore $(<0.07 \% \mathrm{P})$, medium-phosphorus ore $(0.07-0.10 \% \mathrm{P})$, or high-phosphorus ore $(>0.10 \% \mathrm{P})[5]$.

High-phosphorus iron ores abound worldwide and constitute the bulk of "low grade" iron ores. For instance, China is reported to have a proven reserve of approximately 4.0 billion tons of low-grade $\left(\mathrm{Fe}_{\text {total }} 35-50 \%\right)$, high-phosphorus $(0.4-1.8 \% \mathrm{P})$ oolitic haematite ore $[6$, 7], while Nigeria is reported to have a proven reserve of 1.25 billion tons of low-grade $\left(\mathrm{Fe}_{\text {total }} 45.6-54.2 \%\right)$, highphosphorus $(0.76-2.69 \% \mathrm{P})$ oolitic goethite ore [8-10]. Australia's reserve of low-phosphorus ore $(<0.07 \% \mathrm{P})$ in Western Australia is estimated [11] to be about 20.4 billion tons and projected [12] to be depleted by 2030, while

Electronic supplementary material The online version of this article (https://doi.org/10.1007/s42452-019-0218-9) contains supplementary material, which is available to authorized users.

Stanley Udochukwu Ofoegbu, ofoegbu.stanley@ua.pt | ${ }^{1}$ Present Address: Department of Materials and Ceramic Engineering, CICECO-Aveiro Institute of Materials, University of Aveiro, Campus Universitário de Santiago, 3810-193 Aveiro, Portugal. ${ }^{2}$ Department of Materials and Metallurgical Engineering, Federal University of Technology, P.M.B 1526, Owerri, Nigeria.

SN Applied Sciences (2019) 1:204 | https://doi.org/10.1007/s42452-019-0218-9 
there are 8.0 billion tons of high-phosphorus ore $(>0.10 \%$ P) [5]. High phosphorus content is reported to account for the non-exploitation of Moncorvo iron ores located in the Trás-os-Montes region, northeast Portugal, and estimated to exceed 1000 million tons of iron ore reserves, arguably among the largest iron ore reserves in Europe [13-15]. The Moncorvo iron ores of Portugal are reported to be low grade ranging in iron content from 35 to 43 wt $\%$ Fe with an average iron content of 37 wt $\% \mathrm{Fe}$, coupled with a high phosphorus content that ranges from 0.3 to $0.7 \mathrm{wt} \% \mathrm{P}$, though phosphorus content in some samples in excess of $1.2 \mathrm{wt} \% \mathrm{P}$ has also been reported [14]. The Moncorvo iron ores of Portugal appear to be the subject of some ongoing valorization research efforts aimed at biodesphosphorization [16]. Table 1 summarizes information on some of the high-phosphorus ores worldwide.

Iron ores with phosphorus content lower than $0.07 \%$ $\mathrm{P}$ are commercially desired as they are suitable for use in iron production. As a consequence, a lot of research efforts have been focused on phosphorus removal from high-phosphorus iron ore $[20,24,32-48]$ in a bid to reduce the $\mathrm{P}$ content to acceptable levels. Processes that had been employed for phosphorus removal from iron ores include thermal treatment [7, 21, 24, 38-41, 49-53], microwave treatment $[38,54-56]$, ultrasonic treatment [54], acid leaching $[12,17,20,49,56-60]$, alkaline leaching $[5,59]$, bioleaching $[30,61-63]$, agglomeration methods [64-67], and froth flotation [31, 52, 68, 69]. For a more detailed appreciation of the methods employed to process and valorize high-phosphorus-content ores, the recent reviews by Quast [70] and by Pereira and Papini [71] are recommended. With an ever-growing demand for natural resources and rapid depletion of high-quality sources for minerals, there arises a need for research on lower-grade minerals to ensure their economic exploitation. In this millennium, the secret of continued availability of some mineral resources might depend on the development of new methods and systems, for refining and using hitherto unusable and hence unexploited mineral grades. In order to achieve this goal, a good understanding of the constitution of each of these mineral sources is vital. Taylor et al. [72] had opined that exploitation of lower-grade iron deposits will probably supplement the dwindling reserves of high-grade ores in the future.

Agbaja iron ore deposit estimated at 1250-2000 million metric tons of ore reserve constitutes the largest known Nigerian iron ore deposit, but is currently under-exploited due to its high phosphorus content. It has been reported to consist of oolitic and pisolitic structures rich in iron oxides, in a predominantly clay matrix $[73,74]$. The principal constituent mineral has been reported to be goethite, with minor quantities of haematite, maghemite, siderite, quartz, kaolinite, pyrite, and an average of $0.09 \%$ S $[8,9$, 73]. The Agbaja iron ore is also reported to have a high phosphorus content in the range of $0.76-2.13 \%[25,26$, 75] which makes its use in iron making in the blast furnace without reduction of the phosphorus content impractical. To overcome this challenge and exploit this huge reserve, a thorough understanding of the ore composition and the partitioning of the elements/compounds present is necessary. In this work therefore, characterization of Agbaja iron ore has been done using a combination of material characterization techniques ranging from optical microscopy, scanning electron microscopy with energy-dispersive
Table 1 High-phosphorus iron ores worldwide

\begin{tabular}{lll}
\hline Name/source & Reported P content (Mass \% P) & References \\
\hline Hubei Province, China & 1.24 & {$[6,17]$} \\
& 1.25 & {$[18]$} \\
Wushan, Chongqing, China & 0.57 & {$[19]$} \\
Hunan Province, China & 1.16 & {$[20]$} \\
Pilbara area of Western Australia & 1.61 & {$[21]$} \\
Lisakovsk ore, Kazakhstan & $0.123-0.146$ & {$[5]$} \\
& 0.94 & {$[22]$} \\
East Aswan region, Egypt & $1.6 *\left(\% \mathrm{P}_{2} \mathrm{O}_{5}\right)$ & {$[23]$} \\
Agbaja iron ore, Nigeria & $3.09-5.64^{*}\left(\% \mathrm{P}_{2} \mathrm{O}_{5}\right)$ & {$[24]$} \\
& $0.76-2.13 \%$ & {$[25,26]$} \\
& 0.76 to $2.69 \%$ & {$[8-10]$} \\
Hunan Province, China & $1.4-2.0 \%$ & {$[27]$} \\
Tula mine ore, Russia & $1.395 \%$ & {$[$ This work] } \\
Moncorvo iron ore, Portugal & 1.61 & {$[21]$} \\
Minas Gerais, Brazil & 0.60 & {$[28]$} \\
& $0.3-0.7$ & {$[14]$} \\
\hline
\end{tabular}


X-ray spectroscopy, powder X-ray diffraction, and thermal gravimetric analysis and differential scanning calorimetry.

The phosphorus in high-phosphorus haematite ore is reported to occur predominantly in the form of apatite $\left(\mathrm{Ca}_{3}\left(\mathrm{PO}_{4}\right)_{2}\right)$ [6]. According to Fisher-White et al. [5], although microscopic inclusions of apatite have been reported in some Australian ores, phosphorus is reported to occur predominantly within the goethite $(\mathrm{a}-\mathrm{FeOOH})$ fraction [76-78] in concentrations that are thought to be indicative of the original amounts of the mineral apatite $\left(\mathrm{Ca}_{5}\left(\mathrm{PO}_{4}\right)_{3} \mathrm{OH}\right)$ in the ore [79]. Phosphorus in the iron ore is reportedly capable of being attached to the goethite, and $\mathrm{FeO}(\mathrm{OH})$ in the form of a solid solution [76]. Wells and Ramanaidou [80] studied the occurrence and mineralogical association of phosphorus in Australian bedded iron ore deposits and concluded that $\mathrm{P}$ is associated mainly with goethite most likely as adsorbed $\mathrm{PO}_{4}$, in the absence of direct experimental evidence of Fe replacement by $P$ within the structure of synthetic goethite that is detectable as changes in lattice parameters. Earlier works based on Australian iron ores had reported [81] that phosphorus can occur in iron ores in wide variety of ways: as microscopic inclusions of hydroxyapatite $\mathrm{Ca}_{5}\left[\mathrm{PO}_{4}\right]_{3}(\mathrm{OH})[82]$, as secondary phosphates such as vivianite, $\mathrm{Fe}_{3}{ }^{2+}\left[\mathrm{PO}_{4}\right]_{2.8} \mathrm{H}_{2} \mathrm{O}$, and wavellite, $\mathrm{Al}_{3}\left[\mathrm{PO}_{4}\right]_{2}(\mathrm{OH}, \mathrm{F})_{3}[83]$, and as rare-earthbearing phosphates [76, 84]. Phosphorus can also occur in iron ores not as discrete mineral phases but incorporated within goethite $[78,85]$, a scenario that is more likely when the average levels of $P$ are of the order of 0.1 per cent or more $[79,81,84,86]$.

An earlier study [8] on Agbaja iron ore had classified it as a low-grade ( $54.17 \mathrm{wt} \% \mathrm{Fe}$ ), high-phosphorus, acidic ore and based on their XRD results reported to be comprised of the minerals: magnetite, goethite, corundum, and quartz, with traces of iron and aluminium phosphates. However, this report is silent regarding the distribution of the phosphorus, a question that is resolved in the present study. In spite of the various reports of phosphorus removal from high-phosphorus iron ores using various techniques mentioned earlier herein, not much is known about the local chemical environment around the phosphorus atom(s) in high-phosphorus iron ores. This knowledge is prone to be valuable for effective and targeted phosphorus removal from the different varieties of highphosphorus iron ores. The local environment around the phosphorus atom in high-phosphorus iron ores is bound to be dependent on its bonding with other elements (such as $\mathrm{Fe}, \mathrm{Si}, \mathrm{O}$, and $\mathrm{Al}$ present in the ore) and hence its chemical presentation/phase (compound). Due to the low percentage of phosphorus (usually less than $3 \% \mathrm{P}$ ) in these ores classified as high-phosphorus iron ores, powder XRD often employed to determine and quantify crystalline phases in ores, is seldom useful in providing the vital insight into the bonding and local chemical environment around the phosphorus atom(s) in high-phosphorus iron ores.

\section{Experimental}

A bulk sample of the ore weighing about $1200 \mathrm{~g}$ was obtained, and $1000 \mathrm{~g}$ of it was mechanically pulverized to powder. From the remainder, a good and representative cross section was obtained, mounted on epoxy resin, and polished progressively with abrasive paper of grit sizes $400,600,800$, and 1000 prior to optical and scanning electron microscopy, and elemental mapping using energy-dispersive spectroscopy. XRF analysis was carried out using the XRF fusion method (lithium borate) on ore sample that had been pulverized by agate milling until more than $85 \%$ of sample passes through 75 -micron sieve. Powder X-ray diffraction was carried out at room temperature using $\mathrm{Cu}-\mathrm{K}_{\mathrm{a}}$ radiation on a Rigaku Geigerflex X-ray powder diffractometer at a speed of $1 \% / \mathrm{min}$ from $10^{\circ}$ to $120^{\circ}$. High-temperature $X$-ray diffraction was also carried out on powder samples at temperatures between 25 and $1220^{\circ} \mathrm{C}$ using $\mathrm{Cu}-\mathrm{K}_{\mathrm{a}}$ radiation on same diffractometer with same parameters. In addition, thermal analysis (TGA and DSC) was carried out simultaneously with a Netzsch STA 409 PC/PG Simultaneous TGA-DSC machine after calibration with $176.500 \mathrm{mg}$ of the ore powder sample using an air flow rate of $100 \mathrm{ml} / \mathrm{min}$ and nitrogen flow rate of $18 \mathrm{ml} /$ min, and heating from 20 to $1250^{\circ} \mathrm{C}$ with a heating rate of $1^{\circ} \mathrm{C} / \mathrm{min}$. The results obtained from the thermal analysis were analysed using Netzsch Proteus Thermal Analysis Software. Scanning electron microscopy, elemental mapping, and energy-dispersive $\mathrm{X}$-ray analysis of the ore were carried out using a Hitachi SU-70 scanning electron microscope with EDS capability provided by a Bruker Quantax 400 EDS system.

\section{Results and discussion}

\subsection{Optical microscopy results}

Optical microscopy results from a polished cross section of the ore (Fig. 1) show the oolitic structure of the ore, composed of lighter spherical grains in concentric layers embedded in a darker matrix. The presentation of the ore is consistent with the structure of oolitic ores.

\subsection{Scanning electron microscopy results}

Figure 2a shows the morphology of the grains of the pulverized iron ore, the sharp edges being consistent with 


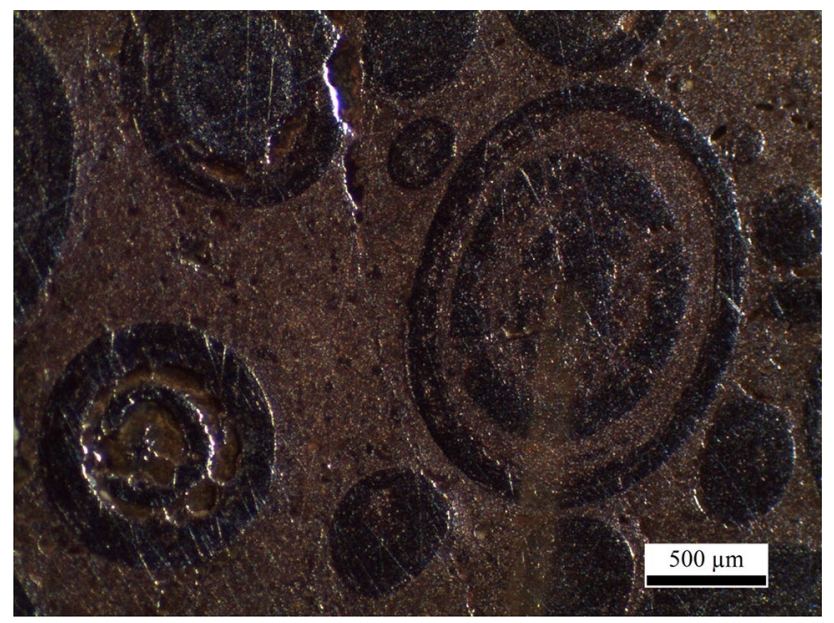

Fig. 1 Optical microscopy image of a bulk of Agbaja iron ore sample mounted on epoxy and polished

mechanical pulverization. The SEM image of a polished cross section of Agbaja iron ore shown in Figure $2 \mathrm{~b}$ reveals with more clarity the oolitic nature of the ore. In this image, the darker areas are predominantly the gangue minerals, while the lighter areas comprise mostly of the iron ore.

\subsection{Scanning electron microscopy with energy-dispersive X-ray spectroscopy with elemental mapping results}

The EDS results (Fig. 3 and supplementary material S-1) confirm the presence of iron, aluminium, silicon, oxygen, and most importantly phosphorus, whereas no minerals containing phosphorus were detected in the powder XRD results, most probably due to the fact that its concentration in the ore (measured to be $1.395 \%$ P; Table 2 ) is below
$3 \% \mathrm{w} / \mathrm{w}$, the detection limit with XRD. The non-detection of hydrogen is obvious as EDS is not suitable for detecting the first five (and light) elements.

Energy-dispersive $\mathrm{X}$-ray elemental mapping of selected elements ( $\mathrm{Fe}, \mathrm{P}, \mathrm{Ca}$, and $\mathrm{Al}$ ) in Fig. 3 shows that aluminium, a distinct component of the gangue (kaolinite$\left.\mathrm{Al}_{4}(\mathrm{OH})_{8} \mathrm{Si}_{4} \mathrm{O}_{10}\right)$, is partitioned into the lighter areas of the SEM image, whereas phosphorus is observed in both the lighter areas (gangue minerals) and the darker areas (iron ore). This observed lack of partitioning of phosphorus is indicative of the futility of attempting to reduce phosphorus content in this ore by physical separation processing methods. This result is consistent with the results from analysis of different fractions of Agbaja iron ore by Mücke et al. [87] which showed the presence of phosphorus in all the different ore fractions.

\subsection{X-ray fluorescence spectroscopy results}

Results of chemical analysis by X-ray fluorescence (Table 2) indicate that the Agbaja iron ore sample used in this work contains $1.395 \% \mathrm{P}$ (equivalent to $3.196 \% \mathrm{P}_{2} \mathrm{O}_{5}$ ) which is consistent with earlier reports $[8,9,25-27]$ and $53.1 \% \mathrm{Fe}$.

\subsection{Powder X-ray diffraction results}

The powder X-ray diffraction results of the as-received ore (Fig. 4) show the Agbaja iron ore sample to comprise mainly of goethite $(\mathrm{a}-\mathrm{FeOOH})$ and kaolinite $\left(\mathrm{Al}_{4}(\mathrm{OH})_{8} \mathrm{Si}_{4} \mathrm{O}_{10}\right)$. The XRD results obtained after thermal analysis up to $1220^{\circ} \mathrm{C}$ (Figs. 4 and 5) indicate the presence of haematite $\left(\mathrm{Fe}_{2} \mathrm{O}_{3}\right)$, together with silica $\left(\mathrm{SiO}_{2}\right)$ and corundum $\left(\mathrm{Al}_{2} \mathrm{O}_{3}\right)$, both products of kaolinite $\left(\mathrm{Al}_{4}(\mathrm{OH})_{8} \mathrm{Si}_{4} \mathrm{O}_{10}\right)$ thermal decomposition. Inability to detect phosphorus in the XRD results in spite of its detection in the EDX results
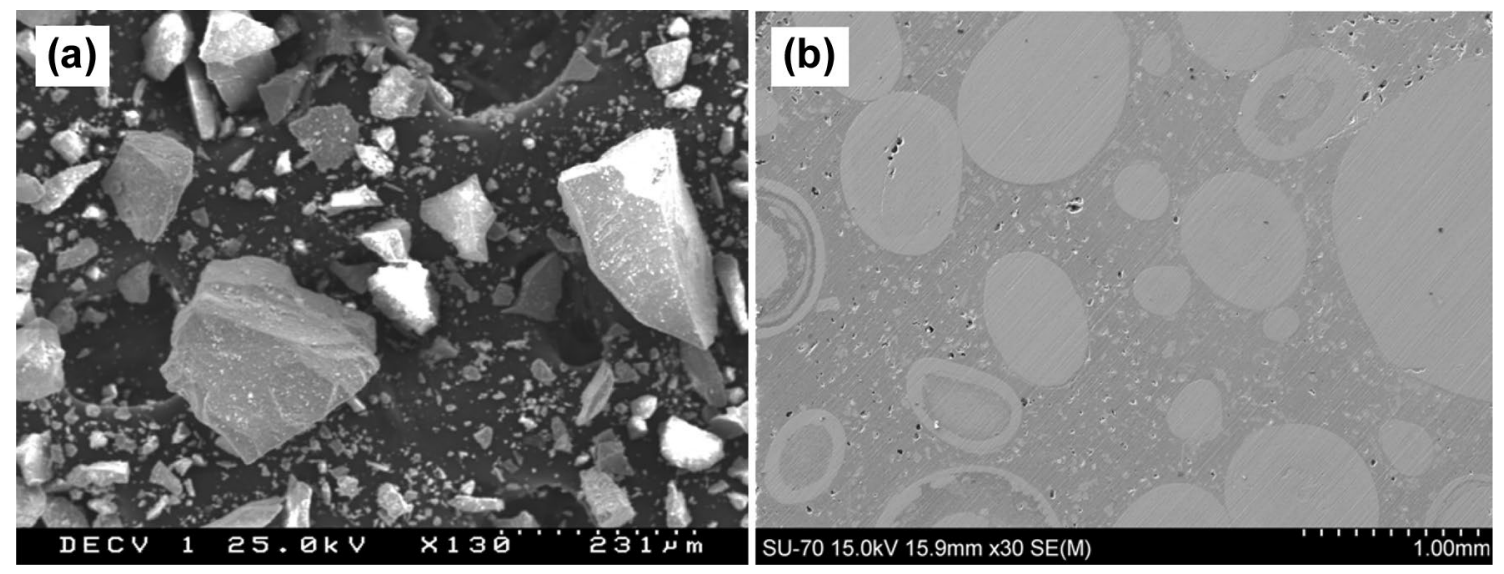

Fig. 2 SEM images of a powdered Agbaja iron ore sample and $\mathbf{b}$ piece of Agbaja iron ore mounted on epoxy and polished (the darker areas are predominantly the gangue minerals, while the lighter areas comprise the iron ore) 

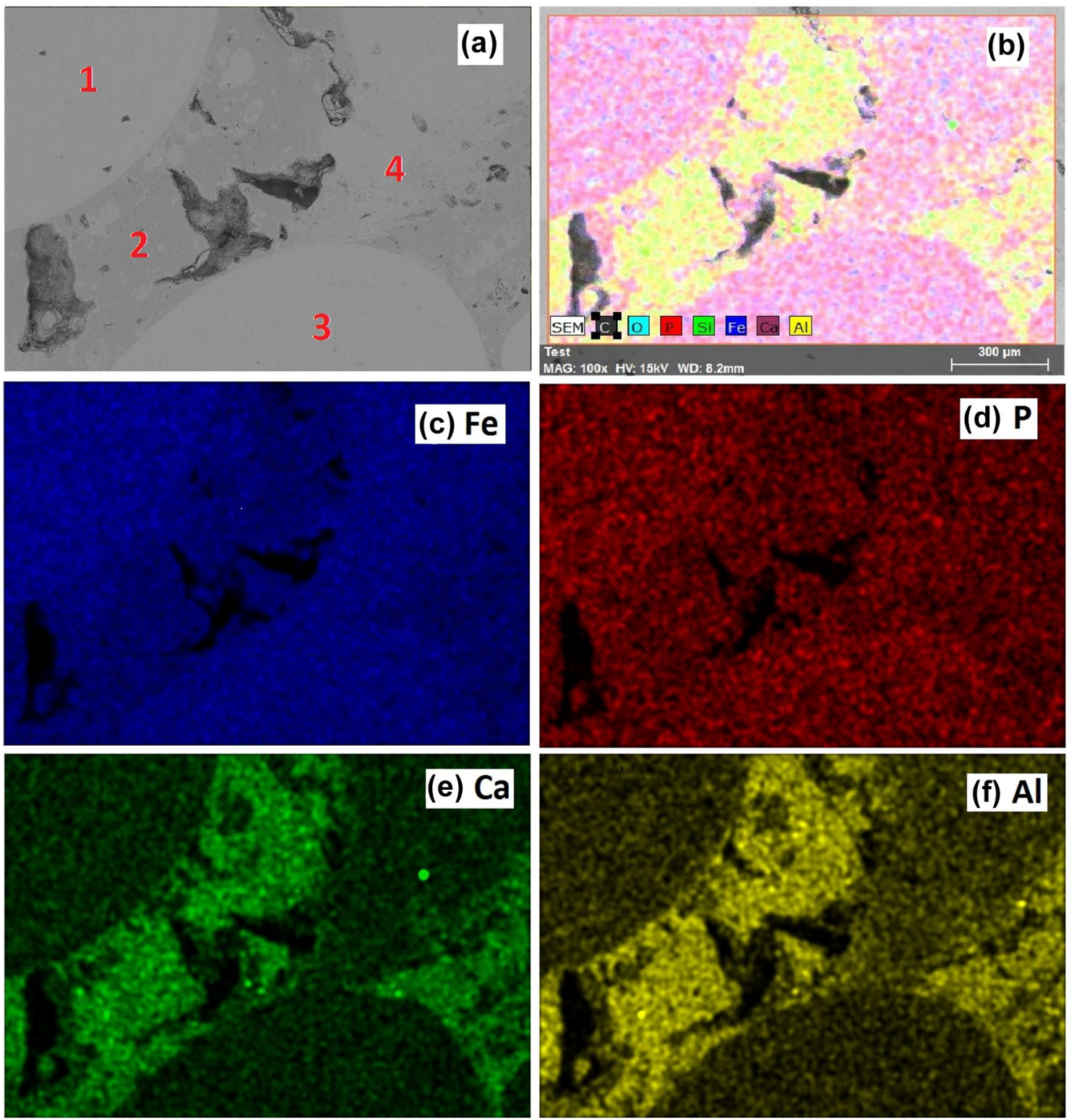

Fig. 3 a SEM image of Agbaja iron ore (2 is predominantly gangue minerals and 1, 3, 4 are iron-rich minerals), $\mathbf{b}$ combined energydispersive X-ray elemental mapping of selected elements; separate

(Fig. 3 and supplementary material S1) is attributed to the probable existence of phosphorus in the iron ore in an amorphous form and/or to the fact that its concentration in the ore, as can be observed from XRF data (Table 2) being quite below $3 \mathrm{wt} \%$ (around the detection limit of $X R D$ ), makes the detection of the crystalline phase containing phosphorus difficult.

In the light of this, it is plausible that phosphorus might exist in Agbaja iron ore as an amorphous phase, and/or as interstitials in the iron oxide/hydroxide structure and probably also in the structure of the aluminosilicates of the gangue. The later possibility has been posited to account

energy-dispersive X-ray elemental mapping of $\mathbf{c}$ iron, $\mathbf{d}$ phosphorus, e calcium, and $\mathbf{f}$ aluminium, showing the distribution of elements in a sample of Agbaja iron ore

for phosphorus in some Australian iron ores [79, 84, 86]. Furthermore, Uwadiale [88] had mentioned that in certain phosphoriferous ore deposits, in which the phosphate mineral(s) are extremely fine grain sized, these phosphate mineral(s) may not be readily identified, even with the use of qualitative SEM with EDAX. Mücke and Farshad [89] in their work on comparison and differentiation of types and subtypes of phanerozoic ooidal ironstones had reported their inability to associate the phosphorus content of Agbaja iron ore with apatite, as they could not detect apatite in spite of the $2.6 \mathrm{wt} \% \mathrm{P}_{2} \mathrm{O}_{5}$ content (equivalent to $1.135 \mathrm{wt} \% \mathrm{P}$ content) in the Agbaja ore sample studied. It 
Table 2 Chemical composition of Agbaja iron ore

\begin{tabular}{|c|c|}
\hline Element/compound & wt $\%$ \\
\hline $\mathrm{Al}_{2} \mathrm{O}_{3}$ & 4.44 \\
\hline As & 0.008 \\
\hline $\mathrm{Ba}$ & $<0.001$ \\
\hline $\mathrm{CaO}$ & 0.07 \\
\hline $\mathrm{Cl}$ & 0.001 \\
\hline Co & 0.006 \\
\hline $\mathrm{Cr}_{2} \mathrm{O}_{3}$ & 0.004 \\
\hline $\mathrm{Cu}$ & 0.001 \\
\hline $\mathrm{Fe}$ & 53.1 \\
\hline $\mathrm{K}_{2} \mathrm{O}$ & 0.012 \\
\hline $\mathrm{MgO}$ & 0.03 \\
\hline $\mathrm{Mn}$ & 0.023 \\
\hline $\mathrm{Na}_{2} \mathrm{O}$ & $<0.005$ \\
\hline $\mathrm{Ni}$ & 0.004 \\
\hline$P$ & 1.395 \\
\hline $\mathrm{Pb}$ & 0.006 \\
\hline S & 0.01 \\
\hline $\mathrm{SiO}_{2}$ & 4.3 \\
\hline Sn & 0.001 \\
\hline $\mathrm{Sr}$ & $<0.001$ \\
\hline $\mathrm{TiO}_{2}$ & 0.12 \\
\hline V & 0.023 \\
\hline $\mathrm{Zn}$ & 0.07 \\
\hline $\mathrm{Zr}$ & 0.001 \\
\hline${ }^{*} \mathrm{LOI}$ at $1000^{\circ} \mathrm{C}$ & 11.68 \\
\hline
\end{tabular}

${ }^{*} \mathrm{LOI}$ is percentage of mass lost on ignition at $1000^{\circ} \mathrm{C}$

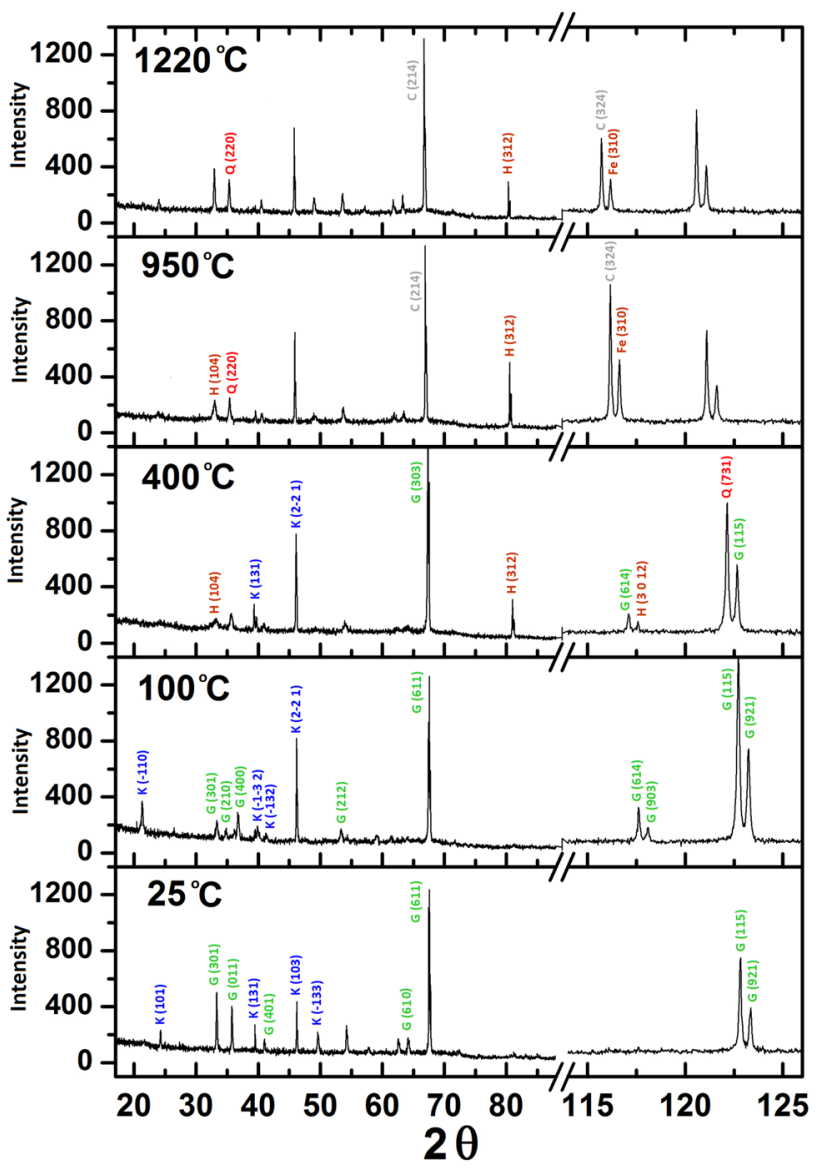

Fig. 5 Powder X-ray diffraction patterns for Agbaja iron ore at different temperatures as sample is heated up from room temperature and maintained at the respective measurement temperatures from 25 to $1220^{\circ} \mathrm{C}$ ( $G$ goethite, $K$ kaolinite, $Q$ quartz/silica, $H$ haematite and $C$ corundum)

is worthy to note that Adedeji and Sale [8] had uniquely reported the presence of traces of iron and aluminium phosphates in Agbaja iron ore which has yet not been confirmed by the reports of later researchers. These reports and the results from the present study favour a postulation that the phosphorus in Agbaja ore is most probably not presenting as a discrete crystalline phase.

By acquiring XRD data as the ore sample is heated up from room temperature, the evolution of crystalline phases as a function of sample temperature was monitored. The results of the high-temperature XRD measurements (Fig. 5) are in agreement with the results of XRD measurements on iron ore samples at ambient temperature, and after heating up to $1220^{\circ} \mathrm{C}$ during TGA/DSC test (Fig. 6), showing that the crystalline phases in Agbaja iron ore at elevated temperatures are haematite, silica, and corundum with no indication of any phosphorus containing phases. Significant changes in the composition of the crystalline phases present in the ore were observed from temperatures

Fig. 4 Powder X-ray diffraction pattern of as-received Agbaja iron ore identifying it as mainly iron oxide hydroxide $(\mathrm{FeO}(\mathrm{OH}))$ with some kaolinite $\left(\mathrm{Al}_{4}(\mathrm{OH})_{8} \mathrm{Si}_{4} \mathrm{O}_{10}\right)$ and same ore after thermal treatment up to $1220^{\circ} \mathrm{C}$ via the TGA/DSC tests identifying its transformation/decomposition to haematite, silica and corundum ( $G$ goethite, $K$ kaolinite, $Q$ quartz/silica, $H$ haematite, and $C$ corundum) 


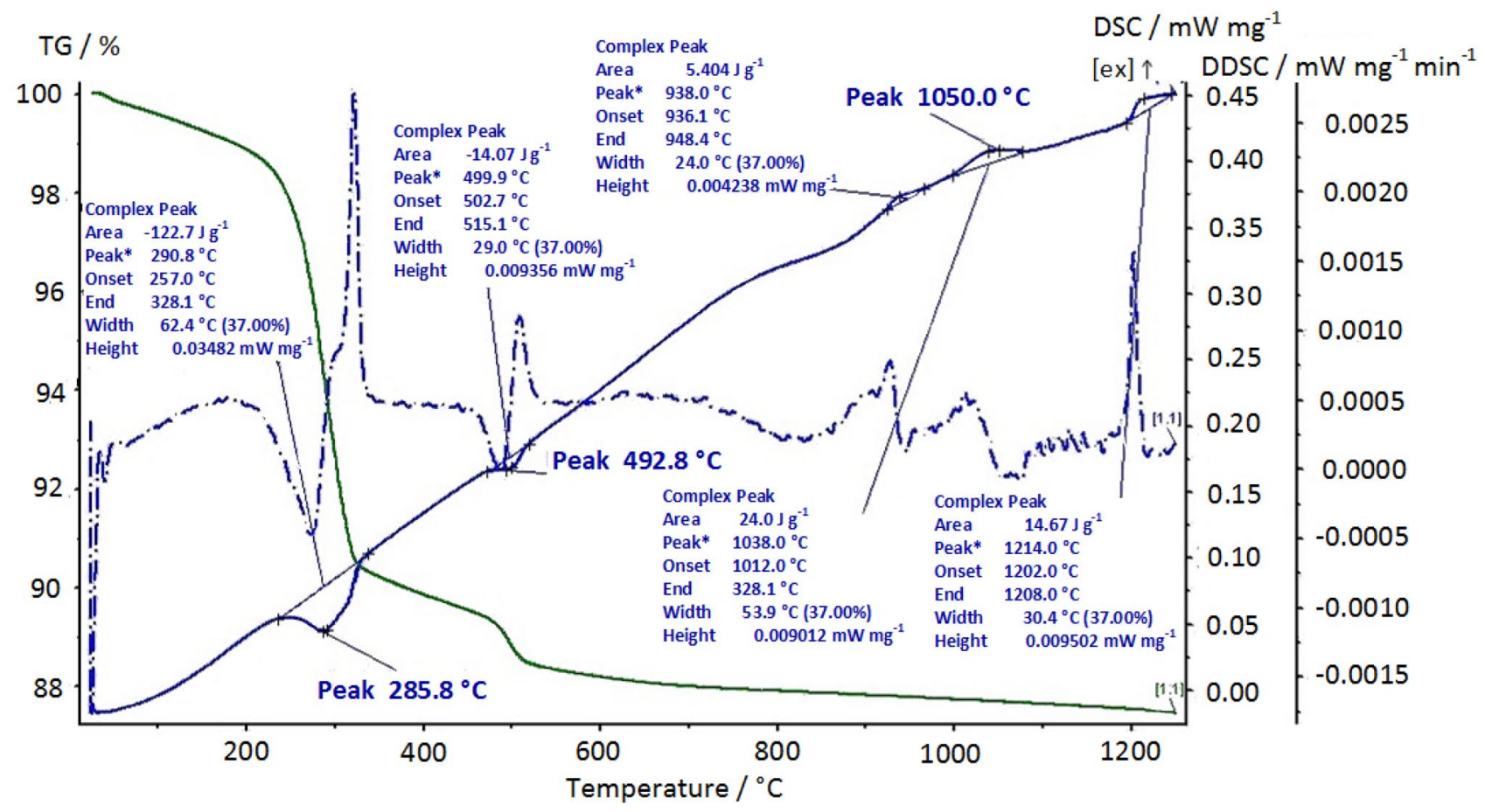

Fig. 6 Combined TGA/DSC plots for Agbaja iron ore with peak analysis results

higher than $400{ }^{\circ} \mathrm{C}$. These results are in agreement with the report of Uwadiale and Whewell [9] who in their work on the effect of temperature on magnetizing reduction of Agbaja iron ore heated Agbaja ore together with coal between 100 and $1000{ }^{\circ} \mathrm{C}$, collected XRD data, and reported the presence of haematite, magnetite, kaolinite, and carbon between 400 and $500^{\circ} \mathrm{C}$; haematite, magnetite, and carbon between 600 and $700^{\circ} \mathrm{C}$; haematite, magnetite, wustite, and carbon between 800 and $900^{\circ} \mathrm{C}$ (with some metallic iron at $900^{\circ} \mathrm{C}$ ); and magnetite, metallic iron, and carbon at $1000^{\circ} \mathrm{C}$.

\subsection{TGA/DSC results}

The thermal analysis results (TGA/DSC) are presented in Fig. 6 and Table 3 (and as supplementary materials S-2 and $\mathrm{S}-3$ ). The most prominent endothermic peak observed in the DSC plot (Table 3; Fig. 6, S-2 and S-3) with onset around $257^{\circ} \mathrm{C}$ and ending at $328^{\circ} \mathrm{C}$ with a peak around $285^{\circ} \mathrm{C}$ is attributed to the hydroxylation of the goethite with the loss of the $\mathrm{OH}$ group in its structure resulting to the formation of haematite $\left(\mathrm{Fe}_{2} \mathrm{O}_{3}\right)$. The dehydroxylation of goethite to form haematite has been reported [90] to occur through intermediate hydroxylated phases, mainly between $250 / 260$ and $400^{\circ} \mathrm{C}[91,92]$, the actual temperature range and kinetics being strongly dependent on such factors as particle size or crystallinity [93], composition (aluminium substitution [94], and water content [95] included), and testing variables like heating rate and duration.

In the obtained thermogravimetric results, the presence of other less intense peaks, particularly at $502{ }^{\circ} \mathrm{C}$ (endothermic) and $938{ }^{\circ} \mathrm{C}$ (exothermic), both below $1000{ }^{\circ} \mathrm{C}$ up to which haematite is thermally stable, is attributed to the major second phase in the ore-kaolinite

Table 3 Results from the analysis of observed peaks in DSC measurements

\begin{tabular}{llclllll}
\hline Peaks & Peak type & Area $(\mathrm{J} / \mathrm{g})$ & Width $\left({ }^{\circ} \mathrm{C}\right)$ & Height $(\mathrm{mW} / \mathrm{mg})$ & Peak onset $\left({ }^{\circ} \mathrm{C}\right)$ & Peak $\left({ }^{\circ} \mathrm{C}\right)$ & Peak end $\left({ }^{\circ} \mathrm{C}\right)$ \\
\hline 1 & Endothermic & -112.7 & 62.4 & $3.482 \times 10^{-2}$ & 257.0 & 290.8 & 328.1 \\
2 & Endothermic & -14.07 & 29.0 & $9.356 \times 10^{-3}$ & 499.9 & 502.7 & 915.1 \\
3 & Exothermic & 5.404 & 24.0 & $4.238 \times 10^{-3}$ & 936.1 & 938.0 & 948.4 \\
4 & Exothermic & 24.0 & 53.9 & $9.012 \times 10^{-3}$ & 1012.0 & 1038.0 & - \\
5 & Exothermic & 11.67 & 30.4 & $9.502 \times 10^{-3}$ & 1202.0 & 1214.0 \\
\hline
\end{tabular}

The asterik was meant to signify the peak with the smallest temperature difference between peak onset and end (in this case it was $6{ }^{\circ} \mathrm{C}$ ) 
$\left(\mathrm{Al}_{4}(\mathrm{OH})_{8} \mathrm{Si}_{4} \mathrm{O}_{10}\right)$-detected in the XRD results. The peak at $502{ }^{\circ} \mathrm{C}$ is hence attributed to the dehydroxylation of kaolinite and possible formation of metakaolinite, which has been reported to occur in the temperature range $400-540{ }^{\circ} \mathrm{C}$ [96]. The relatively low observed temperature for this reaction $\left(502{ }^{\circ} \mathrm{C}\right)$ is indicative of poor ordering in the crystalline structure of the kaolinite $[96,97]$. The exothermic peaks observed at 938,1038 , and $1202{ }^{\circ} \mathrm{C}$ are attributed to recrystallization and transformation of dehydration products to metakaolinite, corundum, and silica [97].

\section{Conclusions}

Agbaja iron ore, a high-phosphorus iron ore, has been characterized using a variety of analysis techniques in an attempt to unravel the presentation and distribution of phosphorus in the iron ore (between the iron-rich phase and the gangue mineral(s) which will be very useful in planning effective beneficiation and phosphorus removal strategies). From the results of this study, the presence of phosphorus is confirmed, its concentration in the sample studied is determined to be $1.395 \mathrm{wt} \% \mathrm{P}$, and its spatial distribution in the ore is demonstrated to be in both the iron-rich phase and the gangue minerals. However, the actual presentation of phosphorus in the ore could not be determined as the XRD results did not show the presence of any phosphorus containing crystalline phases (minerals). This might be indicative of the plausible presence of phosphorus in Agbaja iron ore as an amorphous phase, and/or as interstitials in the iron oxide/hydroxide structure, and probably also in the structure of the aluminosilicates of the gangue mineral(s).

Acknowledgements S.U. Ofoegbu acknowledges the European Union for sponsorship through the Erasmus Mundus Scholarship Programme (EMMS-2008), and the Vice Chancellor, Federal University of Technology Owerri, Nigeria, for study leave approval (2008-2010).

\section{Compliance with ethical standards}

Conflict of interests The author states that there is no conflict of interest.

\section{References}

1. USEPA (1994). Extraction and beneficiation of ores and minerals. Technical resource document: Iron. vol 3. EPA 530-R-94-030, NTIS PB94-195203, p 122

2. Weiss NL (ed) (1985) SME mineral processing handbook, vol 1 and 2. Society of Mining Engineers of the American Institute of Mining, Metallurgical and Petroleum Engineers Inc, NewYork, NY
3. Upadhyay RK, Venkatesh AS (2006) Current strategies and future challenges on exploration, beneficiation and value addition of iron ore resources with special emphasis on iron ores from eastern India. Appl Earth Sci 115:187-195. https:// doi.org/10.1179/174327506X138922

4. Cheng CT, Misra VN, Clough J, Muni R (1999) Dephosphorisation of western Australian iron ore by hydrometallurgical process. Miner Eng 12:1083-1092. https://doi.org/10.1016/ S0892-6875(99)00093-X

5. Fisher-White MJ, Lovel RR, Sparrow GJ (2012) Phosphorus removal from goethitic iron ore with a low temperature heat treatment and a caustic leach. ISIJ Int 52:797-803. https://doi. org/10.2355/isijinternational.52.797

6. Zhu D, Guo Z, Pan J, Zhang F (2016) Synchronous upgrading iron and phosphorus removal from high phosphorus oolitic hematite ore by high temperature flash reduction. MetalsBasel 6:123. https://doi.org/10.3390/met6060123

7. Li KQ, Wen NI, Ming ZHU, Zheng MJ, Yuan LI (2011) Iron extraction from oolitic iron ore by a deep reduction process. J Iron Steel Res Int 18:9-13. https://doi.org/10.1016/S1006 -706X(11)60096-4

8. Adedeji FA, Sale FR (1984) Characterization and reducibility of Itakpe and Agbaja (Nigerian) iron ores. Clay Miner 19:843-856. https://doi.org/10.1180/claymin.1984.019.5.12

9. Uwadiale GGOO, Whewell RJ (1988) Effect of temperature on magnetizing reduction of Agbaja iron ore. Metall Mater Trans B 19:731-735. https://doi.org/10.1007/BF02650192

10. Proceedings of the Nigerian Metallurgical Society (1999) 10th annual conference, Jos, Nigeria pp 14-16

11. Ramanaidou ER (2010) Personal communication, to FisherWhite MJ, Lovel RR, Sparrow GJ, (2012) in Ref 5

12. Araujo A, Fonseca D, Souza C (1994) Hydrometallurgical routes for the reduction of phosphorus in iron ores. A. Sutulov Meml 3:83-92

13. Durães N, da Silva EF, Bobos I, Ávila P (2014) Rare Earth Elements fractionation in native vegetation from the Moncorvo iron Mines, NE Portugal. Procedia Earth Planet Sci 10:376-382. https://doi.org/10.1016/j.proeps.2014.08.064

14. d'Orey FLC (1999) The detrital origin of the Moncorvo Ordovician ironstones. Ciências da Terra (UNL) 13:131-140

15. Mikami HM (1944) World iron-ore map. Econ Geol 39:1-24. https://doi.org/10.2113/gsecongeo.39.1.1

16. New industrial solutions to treat high $\mathrm{P}$ iron ores - case study of the Moncorvo iron ore. https://ec.europa.eu/growth/toolsdatabases/eip-raw-materials/en/content/new-industrialsolutions-treat-high-p-iron-ores-\%E2\%80\%93-case-studymoncorvo-iron-ore. Accessed 1 July 2018

17. Muhammed M, Zhang $Y$ (1989) A hydrometallurgical process for the dephosphorization of iron ore. Hydrometallurgy 21(3):277-292

18. Tang H, Guo Z, Zhao Z (2010) Phosphorus removal of high phosphorus iron ore by gas-based reduction and melt separation. J Iron Steel Res Int 17:1-6. https://doi.org/10.1016/S1006 -706X(10)60133-1

19. Wang HH, Li GQ, Zhao D, Ma JH, Yang J (2017) Dephosphorization of high phosphorus oolitic hematite by acid leaching and the leaching kinetics. Hydrometallurgy 171:61-68. https://doi. org/10.1016/j.hydromet.2017.04.015

20. Xia WT, Ren ZD, Gao YF (2011) Removal of phosphorus from high phosphorus iron ores by selective $\mathrm{HCl}$ leaching method. J Iron Steel Res Int 18:1-4. https://doi.org/10.1016/S1006 -706X(11)60055-1

21. Li G, Zhang S, Rao M, Zhang Y, Jiang T (2013) Effects of sodium salts on reduction roasting and Fe-P separation of high-phosphorus oolitic hematite ore. Inter J Miner Process 124:26-34. https://doi.org/10.1016/j.minpro.2013.07.006 
22. Akatov Al, Lyashenko AG, Toptalova IN (1969) Obogashch Rud, 14(3) (1969), 47; Chem Abs, 72 (1970), 69543h (in Russian)

23. Khassen B, Baltynova N, Dakhno L (2014) Investigation of dephosphorization of brown iron ore concentrates by sintering and magnetic beneficiation. Int J Miner Process 126:136-140. https://doi.org/10.1016/j.minpro.2013.11.013

24. Omran M (2015) Microwave dephosphorisation of high P iron ores of the Aswan region, Egypt-Developing a novel process for high phosphorus iron ore utilization. PhD. Thesis, University of Oulu, Finland. https://doi.org/10.13140/rg.2.2.25732.01925

25. Uwadiele GGOO (1991) Electrolytic coagulation and selective flocculation of Agbaja iron Ore. J Minning Geol 27:77-85

26. Amadi NJ, Odunaike AA, Marthur GP (1982) Preliminary bench scale beneficiation studies with three lumps of iron ore sample from Agbaja. Technical Report, Central Metallurgical and Development Institute, Jos, Nigeria

27. Baba AA, Adekola FA, Folashade AO (2005) Quantitative leaching of a Nigerian iron ore in hydrochloric acid. J Appl Sci Environ Mgt 9:15-20. https://doi.org/10.4314/jasem.v9i3.17346

28. Uwadiale GGOO (1989) Upgrading Nigerian iron ores. Min, Metall Explor 6:117-123. https://doi.org/10.1007/BF03402701

29. Mammadov K (2016) Dephosphorization of iron ore through bioleaching, Instituto Politécnico de Bragança, Portugal. M.Sc Thesis. http://hdl.handle.net/10198/13176

30. Anyakwo CN, Obot OW (2011) Phosphorus degradation capability of Aspergillus terreus on Nigeria's Agbaja Iron Ore. J Miner Mater Char Eng 10:1189-1196

31. Ranjbar M (2002) Dephosphorization of iranian iron oxide fines by flotation. Erzmetall 55:612-616

32. Jones JT, George AS (1908) Method of dephosphorizing and reducing iron ore. U.S. Patent 890,233

33. Jie W, Zhijun W, Mingjin C (2011) Development of technologies for high phosphorus oolitic hematite utilization. Steel Res Int 82:494-500. https://doi.org/10.1002/srin.201100040

34. Jiang T, Dong HG, Guo YF, Li GH, Yang YB, Zhang YB, Li Q (2008) Study on beneficiation and dephosphorization of refractory oolitic hematite ore. In Proceedings of XXIV international mineral processing congress, Science Press, Beijing, vol. 2, pp $1755-1760$

35. Ionkov K, Gaydardzhiev S, de Araujo AC, Bastin D, Lacoste M (2013) Amenability for processing of oolitic iron ore concentrate for phosphorus removal. Miner Eng 46:119-127. https:// doi.org/10.1016/j.mineng.2013.03.028

36. Ionkov K, Gaydardzhiev S, Bastin D, de Araujo AC, Lacoste M (2012) Removal of phosphorous through roasting of oolitic iron ore with alkaline earth additives. In: Proceedings of the XXVI international mineral processing congress. New Delhi, pp 2194-2205

37. Ionkov K, Gomes O, Neumann R, Gaydardzhiev S, Corea de Araujio A (2016) Process oriented characterisation of oolitic iron concentrate during dephosphorisation by roasting and leaching. In: Proceedings of the XXVIII international mineral processing congress (IMPC 2016). The Canadian Institute of Mining, Metallurgy and Petroleum

38. Omran M, Fabritius T, Mattila R (2015) Thermally assisted liberation of high phosphorus oolitic iron ore: a comparison between microwave and conventional furnaces. Powder Technol 269:714. https://doi.org/10.1016/j.powtec.2014.08.073

39. Tang H, Qin Y, Qi T (2016) Phosphorus removal and iron recovery from high-phosphorus hematite using direct reduction followed by melting separation. Miner Process Extr Metall Rev 37:236245. https://doi.org/10.1080/08827508.2016.1181628

40. Gao JT, Guo L, Zhon YW, Ren HR, Guo ZC (2016) Removal of phosphorus-rich phase from high-phosphorous iron ore by melt separation at $1573 \mathrm{~K}$ in a super-gravity field. Int J Miner Metall Mater 23:743-750. https://doi.org/10.1007/s12613-016-1288-y
41. Gao J, Guo L, Guo Z (2015) Separation of P phase and Fe phase in high phosphorus oolitic iron ore by ultrafine grinding and gaseous reduction in a rotary furnace. Metall Materi Trans B 46:2180-2189. https://doi.org/10.1007/s11663-015-0400-4

42. Jun Jl (2003) Study on dephosphorization technology for high-phosphorus iron ore min. Metall 12:33-37

43. Matinde E, Hino M (2011) Dephosphorization treatment of high phosphorus iron ore by pre-reduction, mechanical crushing and screening methods. ISIJ Inter 51:220-227. https://doi. org/10.2355/isijinternational.51.220

44. Matinde E, Hino M (2011) Dephosphorization treatment of high phosphorus iron ore by pre-reduction, air jet milling and screening methods. ISIJ Inter 51:544-551. https://doi. org/10.2355/isijinternational.51.544

45. Zhang Y, Muhammed M (1990) An integrated process for the treatment of apatite obtained from dephosphorization of iron ore. J Chem Technol Biotechnol 47:47-60. https://doi. org/10.1002/jctb.280470107

46. Tian ZH, Li BH, Zhang XM, Jiang ZH (2009) Double slag operation dephosphorization in BOF for producing low phosphorus steel. J Iron Steel Res Int 16:6-14. https://doi.org/10.1016/ S1006-706X(09)60036-4

47. Hui SC, Dai HX (2008) Status quo and prospects of phosphorus reduction of iron ore. Yunnan Metall 6:8

48. Khassen B, Baltynova N, Dakhno L (2014) Investigation of dephosphorization of brown iron ore concentrates by sintering and magnetic beneficiation. Int Miner Process 126:136140. https://doi.org/10.1016/j.minpro.2013.11.013

49. Feld IL, Franklin TW, Lampkin WM, Interior USA (1968) Process for removing phosphorus from iron ores. U.S. Patent 3,402,041

50. Xu CY, Sun TC, Jue K, Li YL, Mo XL, Tang LG (2012) Mechanism of phosphorus removal in beneficiation of high phosphorous oolitic hematite by direct reduction roasting with dephosphorization agent. Trans Nonferrous Met Soc China 22:2806-2812. https://doi.org/10.1016/S1003-6326(11)61536-7

51. Zhu DQ, Chun TJ, Pan J, Lu LM, He Z (2013) Upgrading and dephosphorization of Western Australian iron ore using reduction roasting by adding sodium carbonate. Int J Miner Metall Mater 20:505-513. https://doi.org/10.1007/s1261 3-013-0758-8

52. Yi XX, Yang DB, LI YW (2008) Research on dressing technology of iron increase phosphorous reduction of oolitic hematite ore in southern Hezhang. Metal Mine 11:179-182

53. Gao P, Li GF, Han YX, Sun YS (2016) Reaction behavior of phosphorus in coal-based reduction of an oolitic hematite ore and pre-dephosphorization of reduced iron. Metals-Basel 6:82. https ://doi.org/10.3390/met6040082

54. Han H, Duan D, Wang X, Chen S (2014) Innovative method for separating phosphorus and iron from high-phosphorus oolitic hematite by iron nugget process. Metall Materi Trans B 45:16341643. https://doi.org/10.1007/s11663-014-0094-z

55. Omran M, Fabritius T, Elmahdy AM, Abdel-Khalek NA, Gornostayev S (2015) Improvement of phosphorus removal from iron ore using combined microwave pretreatment and ultrasonic treatment. Sep Purif Technol 156:724-737. https://doi. org/10.1016/j.seppur.2015.10.071

56. Song S, Campos-Toro EF, López-Valdivieso A (2013) Formation of micro-fractures on an oolitic iron ore under microwave treatment and its effect on selective fragmentation. Powder Technol 243:155-160. https://doi.org/10.1016/j.powtec.2013.03.049

57. Cai X, Qian G, Zhang B, Chen Q, Hu C (2018) Selective Liberation of High-Phosphorous Oolitic Hematite Assisted by Microwave Processing and Acid Leaching. Miner-Basel 8:245. https://doi. org $/ 10.3390 / \min 8060245$

58. Yu J, Guo Z, Tang H (2013) Dephosphorization treatment of high phosphorus oolitic iron ore by hydrometallurgical process 
and leaching kinetics. ISIJ Inter 53:2056-2064. https://doi. org/10.2355/isijinternational.53.2056

59. Guo L, Gao J, Zhong Y, Gao H, Guo Z (2015) Phosphorus removal of high phosphorous oolitic iron ore with acid-leaching fluidized-reduction and melt-separation process. ISIJ Int 55:18061815. https://doi.org/10.2355/isijinternational.ISIJINT-2015-135

60. Jin YS, Jiang T, Yang YB, Li Q, Li GH, Guo YF (2006) Removal of phosphorus from iron ores by chemical leaching. J Cent South Univ Technol 13:673-677. https://doi.org/10.1007/s1177 1-006-0003-y

61. Shen S, Rao R, Wang J (2013) Application of indigenous sulfuroxidizing bacteria from municipal wastewater to selectively bioleach phosphorus from high-phosphorus iron ore: effect of particle size. Environ Technol 34:173-180. https://doi. org/10.1080/09593330.2012.689363

62. Buis $P$ (1995). Bioremediation techniques for the removal of phosphorus from iron ore PhD (Doctoral dissertation, Dissertation. Mining engineering. Michigan Technological University, USA

63. Nautiyal CS (1999) An efficient microbiological growth medium for screening phosphate solubilizing microorganisms. FEMS Microbiol Lett 170:265-270. https://doi. org/10.1111/j.1574-6968.1999.tb13383.x

64. Delvasto P, Valverde A, Ballester A, Munoz JA, González F, Blazquez ML, Igual JM, García-Balboa C (2008) Diversity and activity of phosphate bioleaching bacteria from a high-phosphorus iron ore. Hydrometallurgy 92(3-4):124-129. https://doi. org/10.1016/j.hydromet.2008.02.007

65. Sirianni AF, Coleman RD, Goodhue EC, Puddington IE (1968) Separation studies of iron ore bodies containing apatite by spherical agglomeration methods. National Research Council of Canada Ottawa (Ontario) Div of Applied

66. Sirianni AF, Capes CE, Puddington JE (1969) Recent experience with the spherical agglomeration process. Can J Chem Eng 47:166-170. https://doi.org/10.1002/cjce.5450470212

67. Sparks BD, Sirianni AF (1974) Beneficiation of a phosphoriferous iron ore by agglomeration methods. Inter J Miner Process 1:231-241. https://doi.org/10.1016/0301-7516(74)90017-9

68. Uwadiale GGOO (1990) Selective oil agglomeration of Agbaja iron ore. Min Metall Explor 7:132-135. https://doi.org/10.1007/ BF03403287

69. Nunes $A P L$, Pinto CLL, Valadão GES, de Magalhães Viana PR (2012) Floatability studies of wavellite and preliminary results on phosphorus removal from a Brazilian iron ore by froth flotation. Miner Eng 39:206-212. https://doi.org/10.1016/j.minen g.2012.06.004

70. Quast K (2018) A review on the characterisation and processing of oolitic iron ores. Miner Eng 126:89-100. https://doi. org/10.1016/j.mineng.2018.06.018

71. Pereira AC, Papini RM (2015) Processes for phosphorus removal from iron ore-a review. Rem-Rev Esc Mlinas 68:331-335. https ://doi.org/10.1590/0370-44672014680202

72. Taylor DJC, Page DC, Geldenhuys P (1988) Iron and steel in South Africa. J S Afr Inst Min Metall 88:73-95. https://hdl.handl e.net/10520/AJA0038223X_1819

73. Uwadiele GGOO (1984) Beneficiation studies of Agbaja iron ore. PhD. Thesis, University of Strathdyde, pp 341. https://ethos.bl. uk/OrderDetails.do?uin=uk.bl.ethos.371094

74. Abimbola AF (1997) Petrographic and paragenetic studies of the Agbaja ironstone formation, Nupe Basin, Nigeria. J Afr Earth Sci 25:169-181. https://doi.org/10.1016/S0899-5362(97)00096-1

75. Uwadiele GGOO, Nwoke MAU (1983) Beneficiation of Agbaja iron ore by reduction roasting - magnetic separation: semi pilot plant scale-up and establishment of residence point of phosphorus. National Steel Council, Metallurgical Research and Tests Division, Jos

SN Applied Sciences

A SPRINGER NATURE journal
76. Graham J (1973) Phosphorus in iron ore from the Hamersley iron formations. Proc Australas Inst Min Metall 246:41-42

77. Harmsworth RA, Kneeshaw M, Morris RC, Robinson CJ, Shrivastava PK (1990) BIF-derived iron ores of the Hamersley Province. Geol Miner Depos Aust Papua New Guinea 1:617-642

78. Dukino RD, England BM, Kneeshaw M (2000) Phosphorus distribution in BIF-derived iron ores of Hamersley Province, Western Australia. Appl Earth Sci 109:168-176. https://doi.org/10.1179/ aes.2000.109.3.168

79. Morris RC, Wolff KH (1985) Genesis of iron ore in banded ironformation by supergene and supergene-metamorphic processes-a conceptual model. Handb Strata-Bound Stratif Depos 13:73-235

80. Wells MA, Ramanaidou ER (2011) Occurrence and mineralogical association of phosphorus in Australian bedded iron ore deposits. Iron Ore. 2011:331-336

81. MacRae CM, Wilson NC, Pownceby MI, Miller PR (2011) The occurrence of phosphorus and other impurities in Australian iron ores. Iron Ore 2011:281-289

82. Morris RC (1973) A pilot study of phosphorus distribution in parts of the Brockman iron formation, Hamersley Group, Western Australia. Western Australia Department of Mines Annual Report, pp 75-81

83. Ostwald J (1981) Mineralogy of Australian iron ores. BHP Techn Bull 25:4-12

84. Ramanaidou ER, Wells M, Belton DX, Verrall M, Ryan C (2008) Mineralogical and microchemical methods for the characterization of high-grade banded iron formation-derived iron ore. Econ Geol (SEG Rev) 15:129-156. https://doi.org/10.5382/Rev.15.05

85. Thorne W, Hagemann S, Webb A, Clout J (2008) Banded iron formation-related iron ore deposits of the Hamersley Province, Western Australia. Econ Geol (SEG Rev) 15:197-221. https://doi. org/10.5382/Rev.15.08

86. Dukino R, England BM (1997) Phosphorus in Hamersley range iron ore. In: Proceedings Ironmaking resources and reserves estimation, pp 197-202

87. Mücke A, Badejoko TA, Akande SO (1999) Petrographic-microchemical studies and origin of the Agbaja Phanerozoic Ironstone Formation, Nupe Basin, Nigeria: a product of a ferruginized ooidal kaolin precursor not identical to the Minette-type. Miner Depos 34:284-296. https://doi.org/10.1007/s001260050 204

88. Uwadiale GGOO (1990) Upgrading fine-grained iron ores: (i) general review (ii) Agbaja iron ore. In: Hanna J, Attia YA (eds) Advances in Fine particles processing. Springer, Boston, pp 401-411. https://doi.org/10.1007/978-1-4684-7959-1_34

89. Mücke A, Farshad F (2005) Whole-rock and mineralogical composition of Phanerozoic ooidal ironstones: comparison and differentiation of types and subtypes. Ore Geol Rev 26:227-262. https://doi.org/10.1016/j.oregeorev.2004.08.001

90. Landers M, Gilkes RJ, Wells MA (2009) Rapid dehydroxylation of nickeliferous goethite in lateritic nickel ore: X-ray diffraction and TEM investigation. Clays Clay Miner 57:751-770. https://doi. org/10.1346/CCMN.2009.0570608

91. Gualtieri AF, Venturelli P (1999) In situ study of goethite-hematite phase transformation by real time synchrotron powder diffraction. Am Mineral 84:895-904. https://doi.org/10.2138/ am-1999-5-625

92. Walter D, Buxbaum G, Laqua W (2001) The mechanism of the thermal transformation from goethite to hematite. JTherm Anal Calorim 63:733-748. https://doi.org/10.1023/A:1010187921227

93. Mackenzie RC, Berggren G (1970) Oxides and hyroxides of higher-valency elements. In: Mackenzie RC (ed) Differential thermal analysis, vol 1. Fundamental aspects. Academic Press London, New York, pp 271-302 
94. Ruan HD, Gilkes RJ (1996) Kinetics of thermal dehydroxylation of aluminous goethite. J Therm Anal Calorim 46:1223-1238. https ://doi.org/10.1007/BF01979237

95. Goss CJ (1987) The kinetics and reaction mechanism of the goethite to hematite transformation. Mineral Mag 51:437-451. https ://doi.org/10.1180/minmag.1987.051.361.11

96. Frost RL, Vassallo M (1996) The dehydroxylation of kaolinite clay minerals using infrared emission spectroscopy. Clays Clay Miner 44:635-651. https://doi.org/10.1346/ccmn.1996.0440506
97. Vacíluká L, Plevová E, Vallová S, Koutník I (2011) Characterization and differentiation of kaolinites from selected Czech deposits using infrared spectroscopy and differential thermal analysis. Acta Geodyn Geomater 8:59-67

Publisher's Note Springer Nature remains neutral with regard to jurisdictional claims in published maps and institutional affiliations. 